\title{
САМООЦІНКА СТАНУ ЗДОРОВ'Я ПАЦІЄНТІВ ТЕРАПЕВТИЧНОГО ПРОФІЛЮ
}

\section{Самооцінка стану здоров'я пацієнтів терапевтичного профрілю}

\section{Ю. А. Моісеєва, М. М. Жуковська}

Комунальний заклад «Міська клінічна лікарня № 4» Дніпровської міської ради

Резюме. Показники стану здоров'я населення України вказують на те, що хронічні неінфрекційні хвороби є визначальними в структурі захворюваності й смертності населення нашої країни і залежать пери за все від способу життя. Найнебезпечнішими чинниками зниження стану здоров'я в Україні є артеріальний тиск та тютюнокуріння, яке зумовлює захворювання як дихальної, так і серцево-судинної систем.

Мета дослідження - проаналізувати анкетні дані щодо самооцінки здоров'я хворих із патологією дихальної і серцево-судинної систем.

Матеріали і методи. Дослідження проводили за матеріалами опитування 60 хворих із пульмонологічними та кардіологічними патологіями за анкетою, розробленою Київським міжнародним інститутом соціології.

Результати. Встановлено, що серед опитаних респондентів переважали особи з досить низьким рівнем матеріального добробуту (яким вистачає на їжу, проте не вистачає грошей на задоволення іншим потреб). В обох групах пацієнтів зареєстровано найменшу кількість заможних осіб. Результати аналізу самооцінки стану здоров'я пацієнтів терапевтичного профрілю показали, що хворі із патологією дихальної системи у 33,3 \% випадків вважають своє здоров'я посереднім, а у 23,3 \% випадків поганим, тоді як пацієнти із серцево-судинними захворюваннями однаковою мірою оцінили своє здоров'я як хороше, посереднє, погане і дуже погане. Стан здоров'я є важливою умовою для відчуття щастя: серед тих, хто має легеневі й серцево-судинні захворювання, більшість почувається недостатньо щасливими (швидше ні, ніж так), а найменший відсоток тих, котріє щасливими. Порівнюючи отримані дані у пацієнтів пульмонологічного і кардіологічного профрілів, можна говорити про те, що за умов практично однакового матеріального добробуту, своє здоров'я як «посереднє» оцінили на 13,3 \% більше пульмонологічних пацієнтів, тоді як на 16,7 \% більше кардіологічних хворих вважають себе нещасливими.

Висновки. У пацієнтів із серцево-судинними та легеневими захворюваннями важливою умовою для відчуття щастя є не тільки стан здоров'я, але й матеріальний добробут та місце проживання.

Ключові слова: серцево-судинні захворювання; легеневі захворювання; самооцінка здоров'я.
Self-assessment of the health condition of therapeutic profile patients

\section{Yu. A. Moiseeva, M. M. Zhukovska}

Municipal Institution "City Clinical Hospital No. 4" of Dnipro City Council

e-mail: moiseeva yuland@tdmu.edu.ua

Summary. The health indicators of the population of Ukraine show that chronic non-communicable diseases are decisive in the structure of morbidity and mortality of the population of our country and depend primarily on lifestyle. The most dangerous factors in declining health in Ukraine are blood pressure and smoking, which cause diseases of both the respiratory and cardiovascular systems.

The aim of the study - to analyze the questionnaire data on the self-assessment of the health of patients with pathology of the respiratory and cardiovascular systems.

Materials and Methods. The study was conducted on the basis of a survey of 60 patients with pulmonary and cardiac pathologies according to a questionnaire developed by the Kyiv International Institute of Sociology.

Results. It was found that among the surveyed respondents there were persons with a rather low level of material well-being (who have money for food but lacked to meet other needs). In both patient groups, the least number of well-to-do individuals is registered. Analysis of the selfassessment of the health status of patients with a therapeutic profile showed that patients with respiratory system pathology in $33.3 \%$ of cases consider their health mediocre, and in $23.3 \%$ of cases - poor, while patients with cardiovascular disease in the same at least rated their health as good, mediocre, bad and very bad. Health is an important prerequisite for happiness: among those who suffer from pulmonary and cardiovascular disease, the vast majority feel unhappy (more likely than not) and the lowest percentage of those who are happy. Comparing the data obtained in patients with pulmonary and cardiac profiles, we can say that in terms of virtually identical material wellbeing, their health was rated as "mediocre" by $13.3 \%$ more than pulmonary patients, while $16.7 \%$ more cardiac patients consider themselves unhappy.

Conclusions. In patients with cardiovascular and pulmonary diseases, not only a state of health, but also material well-being and a place of residence are important conditions for happiness.

Key words: cardiovascular diseases; pulmonary diseases; health self-assessment. 


\section{ВСТУП}

Оцінка стану здоров'я населення України містить суперечливі дані. За даними одних дослідників, можна вважати здоровими 20 \% населення, за іншими - що лише 5 \% населення дійсно здорові, за даними соціологічних опитувань лише $15 \%$ українців вважають себе здоровими [1]. За даними Держстату в 2017 р., серед населення працездатного віку добрий стан здоров'я зазначили 61 \% чоловіків та 53 \% жінок, серед населення старше працездатного віку добре себе почували 11 \% чоловіків і $6 \%$ жінок [2]. В. Тимошевська звертає увагу на те, що за даними дослідження «Індекс здоров'я. Україна» за останні три роки в Україні спостерігаємо позитивну динаміку зростання кількості людей, які оцінюють свій стан здоров'я як добий або дуже добрий: із 39 \% у 2016 р. до $47 \%$ у 2017 р. та 48 \% у 2018 р. [3]. Показники стану здоров'я населення України вказують на те, що хронічні неінсрекційні хвороби є визначальними в структурі захворюваності й смертності населення нашої країни і залежать перш за все від способу життя (поширення шкідливих звичок, зміна традицій харчування, підвищення рівня психоемоційних навантажень, зниження фрізичної активності населення тощо) [4, 5]. Найнебезпечнішими чинниками зниження стану здоров'я в Україні $€$ артеріальний тиск та тютюнокуріння, яке зумовлює захворювання як дихальної, так і серцево-судинної систем [6].

Метою дослідження було проаналізувати анкетні дані щодо самооцінки здоров'я хворих із патологією дихальної і серцево-судинної систем.

\section{МЕТАРІАЛИ I МЕТОДИ}

Дослідження проводили за матеріалами опитування хворих із пульмонологічними та кардіологічними патологіями за анкетою, розробленою Київським міжнародним інститутом соціології, яка структурно складалась 3 наступних категорій запитань: 1) матеріальний добробут, 2) самооцінка здоров'я та 3) відчуття щастя. Участь в опитуванні взяли 60 осіб, які проживають у Дніпровській області. Опитування проводили з дотриманням принципів біоетики та деонтології і здійснювали у формі багатофракторного анкетування. В анкеті були запитання із великим вибором відповідей.

\section{РЕЗУЛЬТАТИ ТА ОБГОВОРЕННЯ}

Встановлено, що серед опитаних респондентів переважали особи з досить низьким рівнем матеріального добробуту (яким вистачає на їжу, проте не вистачає грошей на задоволення інших потреб). В обох групах пацієнтів зареєстровано найменшу кількість заможних осіб (рис. 1).

Результати аналізу самооцінки стану здоров'я пацієнтів терапевтичного профрілю показали, що хворі з патологією дихальної системи у 33,3 \% випадків вважають своє здоров'я посереднім, а у 23,3 \% випадків - поганим, тоді як пацієнти із серцево-судинними захворюваннями однаковою мірою оцінили своє здоров'я як хороше, посереднє, погане і дуже погане (рис. 2).

Стан здоров'я $€$ важливою умовою для відчуття щастя: серед тих, хто має легеневі й серцево-судинні захворювання, більшість почувається недостатньо щасливою (швидше ні, ніж так), а найменший відсоток тих, котрі $€$ щасливими (рис. 3).

Порівнюючи отримані дані у пацієнтів пульмонологічного і кардіологічного профрілів, можна говорити про те, що за умов практично однакового матеріального добробуту, своє здоров'я як «посереднє» оцінили на 13,3 \% більше пульмонологічних пацієнтів, тоді як на 16,7 \% більше кардіологічних хворих вважають себе нещасливими.

Результати аналізу отриманих даних, відносно відчуття щастя, показали, що серед хворих із серцевою патологією, які вважають себе недостатньо щасливими, 33,3 \% міських і 66,7 \% сільських жителів, при цьому 25,0 \% є бідними, 25,0 \% - 3 досить низьким рівнем матеріального добробуту, 58,3 \% - із середнім рівнем матеріального добробуту і 16,7 - заможні. Варто відмітити, що ця части-

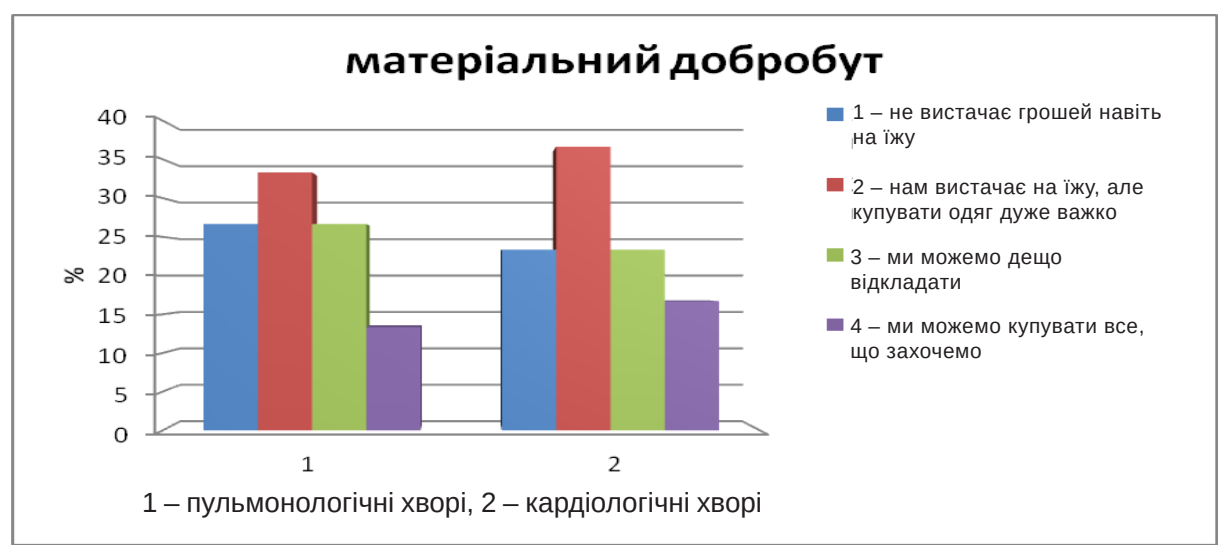

Рис. 1. Зіставлення матеріального добробуту пацієнтів пульмонологічного і кардіологічного профілів, яких включили у дослідження.

ISSN 2706-6282(print)

ISSN 2706-6290(online)
Вісник медичних і біологічних досліджень

Bulletin of Medical and Biological Research 


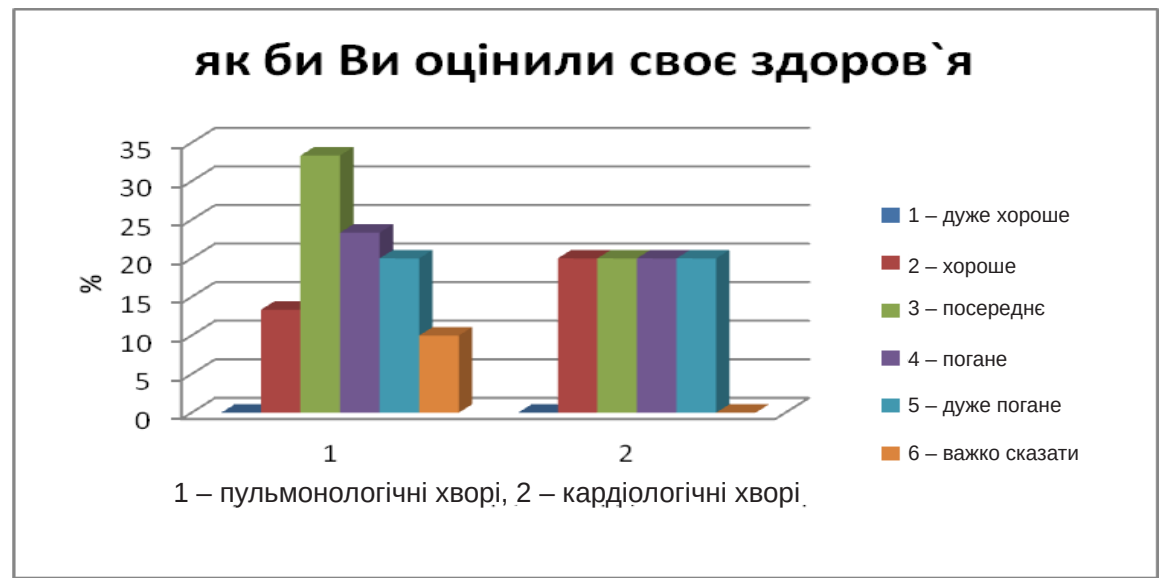

Рис. 2. Поділ пацієнтів пульмонологічного і кардіологічного профілів, яких включили у дослідження, за самооцінкою здоров'я.

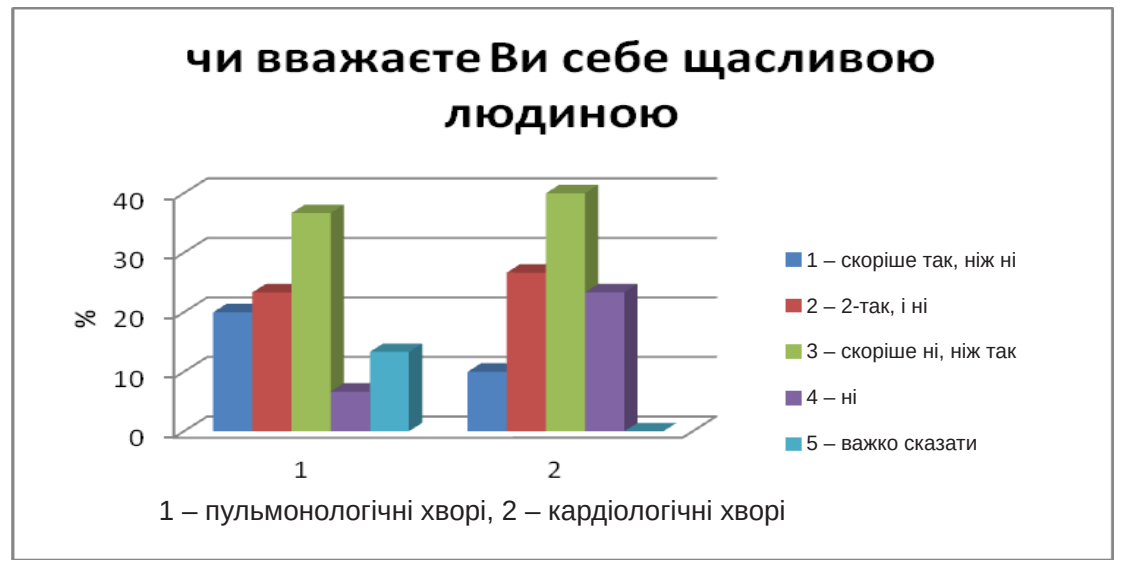

Рис. 3. Поділ пацієнтів пульмонологічного і кардіологічного профілів, яких включили у дослідження, за відчуттям щастя.

на респондентів оцінила своє здоров'я у 25,0 \% як хороше і 75,0 \% як посереднє. Серед 8 пацієнтів із захворюваннями серцево-судинної системи, які були відносно щасливими, переважали міські жителі (75,0 \%) стосовно сільських (25,0 \%), при цьому 87,5 \% з досить низьким рівнем матеріального добробуту, а 12,5 \% - бідні респонденти. Необхідно зазначити, що ця частина респондентів оцінила своє здоров'я у 50,0 \% як посереднє, 25,0 \% як погане і 25,0 \% - як дуже погане. Серед хворих із серцево-судинною патологією, які вважають себе нещасливими, 28,6 \% міських і 71,4 \% - сільських жителів, при цьому 42,9 \% є бідними, 14,3 \% - 3 досить низьким рівнем матеріального добробуту і 42,9 \% - заможні. Варто відмітити, що ця частина респондентів оцінила своє здоров'я у 25,0 \% як хороше і 75,0 \% як посереднє.

Результати аналізу отриманих даних, відносно відчуття щастя, показали, що серед хворих із легеневою патологією, які вважають себе щасливими, 33,3 \% - міських і 66,7 \% - сільських жителів, при цьому 33,3 \% із середнім рівнем матеріального добробуту і 66,7 \% - заможні. Варто відмітити, що ця частина респондентів оцінила своє здоров'я у 50,0 \% як хороше і 50,0 \% як посереднє. Серед 7 пацієнтів із захворюваннями дихальної системи, які були відносно щасливими, переважали міські жителі (71,4 \%) стосовно сільських (28,6 \%), при цьому 71,4 \% з досить низьким рівнем матеріального добробуту, а 28,6 \% - із середнім рівнем достатку. Необхідно зазначити, що ця частина респондентів оцінила своє здоров'я у 42,9 \% як посереднє і у 42,9 \% як погане. Серед хворих із легеневою патологією, які вважають себе недостатньо щасливими, 45,5 \% - міських і 54,5 \% - сільських жителів, при цьому 45,5 \% є бідними, 36,4 \% - 3 досить низьким рівнем матеріального добробуту і 18,2 \% - із середнім рівнем достатку. Варто відмітити, що ця частина респондентів оцінила своє здоров'я у 9,1 \% випадків як хороше, у 25,0 \% як посереднє, у 36,4 \% як погане і у $18,2 \%$ як дуже погане.

Результати проведеного аналізу дозволяють припустити, що на відчуття щастя впливає рівень матеріального добробуту, а також самооцінка стану здоров'я. При цьому варто зазначити, що місце проживання не впливало на досліджувані показники у пульмонологічних хворих, тоді як сільські меш- 
канці з патологією серцево-судинної системи, незважаючи на практично однаковий матеріальний стан й самооцінку стану здоров'я, відчували себе менш щасливими, стосовно міських жителів. Отримані дані вказують на те, що на відчуття щастя впливає не тільки стан здоров'я, але й місце проживання та інші чинники, які не досліджувалися.

Аналізуючи отримані результати, необхідно враховувати дані Держстату за 2017 р., в яких зазначено, що найбільша частка населення, яка оцінила стан свого здоров'я як «добрий», спостерігалась у Львівській, Тернопільській, Чернівецькій, ІваноФранківській, Закарпатській, Київській, Одеській та Волинській областях (66-56 \%), а найнижча - у Дніпропетровській, Запорізькій, Черкаській, Чернігівській та Харківській областях (42-34 \%). При цьому для Дніпропетровської, Запорізькій та Харківської

\section{СПИСОК ЛІТЕРАТУРИ}

1. Волошко Н. І. Детермінанти ставлення до здоров'я і здорового способу життя / Н. І. Волошко // Проблеми сучасної психології. - 2011. - № 11. - С. 115-124.

2. www.ukrstat.gov.ua

3. https://www.bbc.com/ukrainian/news-48025728

4. Особливості харчової поведінки хворих на аліментарне ожиріння та роль медичної сестри у її корекції / М. С. Люблінська, І. В. Пірус, В. А. Мусієнко [та ін.] // Медсестринство. - 2019. - № 1. - С. 15-18.

5. Роль медичної сестри у попередженні впливу метеорологічних факторів на стан пацієнтів з гіпертонічною хворобою / О. П. Мялюк, М. І. Марущак, І. Я. Криницька [та ін.] // Медсестринство. - 2017. - № 1. - С. 9-14.

6. Цібровський О. М. Здоров'я населення і фрактори ризику, що впливають на його стан, як об'єкт управління : огляд літератури / О. М. Цібровський // Україна. Здоров'я нації. - 2015. - № 2(34). - С. 13-19.

7. Заюков І. В. Територіальні особливості самооцінки

\section{REFERENCES}

1. Voloshko NI. [Determinants of attitude to health and healthy lifestyle]. Problemy suchasnoi psykholohii. 2011;1: 11524. Available from: http://lib.iitta.gov.ua/6294/1/1.Pdf. Ukrainian.

2. www.ukrstat.gov.ua

3. https://www.bbc.com/ukrainian/news-48025728

4. Lublinska MS, Pirus IV, Musienko VA, Tsipkalo Al, Marushchak MI. [Features of nutritional behavior of patients with alimentary obesity and the role of nurses in her correction]. Medsestrynstvo. 2019; 1:15-18. Available from: https://doi.org/10.11603/2411-1597.2019.1.9978. Ukrainian.

5. Mialiuk OP, Maruschak MI, Krynytska IY, Rudenko OV. [The role of the nurse in preventing the effects of meteorological factors on the status of patients with hypertension]. Medsestrynstvo. 2018;1: 9-14. Available from: https://doi.org/10.11603/2411-1597.2017.1.8477. Ukrainian.

6. Tibrovskyi OM. [Population health and risk factors affecting its condition as a management object (literature review)]. Ukraina. Zdorovia natsii. 2015;2(34): 13-9. Ukrainian. областей характерні також високі рівні урбанізації та розвитку промисловості [2].

На нашу думку, на низьке відчуття щастя впливають, з одного боку, проблеми 3 доступністю послуг лікарів, висока вартість ліків, медичних товарів, послуг охорони здоров'я, а з іншого, спосіб життя людини. Роль медичної сестри полягає у широкому комплексі санітарно-гігієнічних та просвітницьких заходів, спрямованих на профрілактику захворювань дихальних шляхів й серцево-судинної системи [10, 11].

\section{ВИСНОВКИ}

У пацієнтів із серцево-судинними та легеневими захворюваннями важливою умовою для відчуття щастя $€$ не тільки стан здоров'я, але й матеріальний добробут та місце проживання.

здоров'я населенням України / І. В. Заюков // Стратегічні пріоритети. Серія: Політика. - 2016. - №. 1. - С. 55-62.

8. Krzepota J. Jakość życia oraz zachowania zdrowotne kobiet zamieszkałych na terenach wiejskich i uczestniczących w zorganizowanych formach aktywności fizycznej / J. Krzepota, D. Sadowska // Marketing i Rynek. 2015. - No. 11 (CD). - S. 253-260.

9. Гржибовський Я. Л. Самооцінка стану здоров'я населення сільської місцевості / Я. Л. Гржибовський, І. С. Миронюк, О. В. Любінець // Intermedical Jornal. 2019. - № I (13). - C. 21-28.

10. Тараненко О. І. Основні фрактори ризику розвитку госпітальних пневмоній та роль медичної сестри у їх профрілактиці / О.І. Тараненко, Д. А. Пасечник, М. І. Марущак // Медсестринство. - 2013. - № 4. - С. 22-26.

11. Особливості перебігу хронічного обструктивного захворювань легень в осіб старшого віку / Ю. Г. Богута, Х. Я. Максів, У. П. Гевко [та ін.] // Медсестринство. - 2017. - № 2. - C. 4-7.

7. Zayukov IV. [Territorial features of self-assessment of health of the population of Ukraine]. Stratehichni priorytety. Seriia: Polityka. 2016;1: 55-62. Ukrainian.

8. Krzepota J. [Quality of life and health behaviors of women living in rural areas and participating in organized forms of physical activity]. Marketing i Rynek. 2015;11: 253-60.

9. Hrzhybovskyi YaL. [Self-assessment of health status of rural population]. Intermedical Jornal. 2019;I(13): 21-8. Ukrainian.

10. Taranenko OI, Pasechnik DA, Maruschak MI. [The main risk factors for the development of hospital pneumonia and the role of the nurse in their prevention]. Medsestrynstvo. 2013;4: 22-26. Ukrainian.

11. Boguta YG, Maksiv KY, Gevko UP, Myalyuk OP, Marushchak MI. [Features of the course of chronic obstructive pulmonary disease in older persons]. Medsestrynstvo. 2017; 2: 4-7. Ukrainian. 